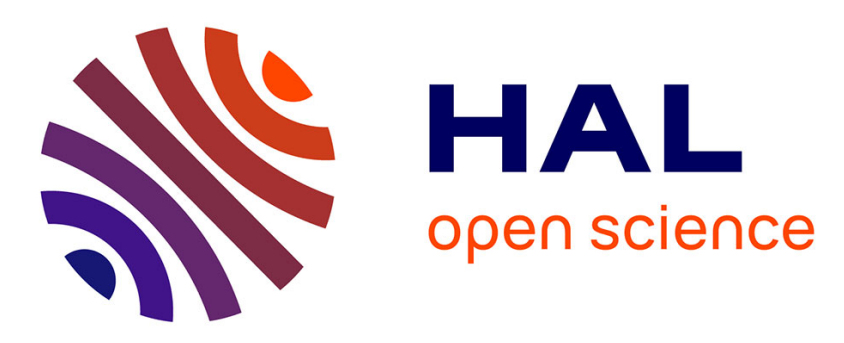

\title{
Stability and performance of two GSBR operated in alternating anoxic/aerobic or anaerobic/aerobic conditions for nutrient removal
}

Ahlem Filali, Angela Manas, Myriam Mercade, Yolaine Bessiere, Béatrice Biscans, Mathieu Sperandio

\section{To cite this version:}

Ahlem Filali, Angela Manas, Myriam Mercade, Yolaine Bessiere, Béatrice Biscans, et al.. Stability and performance of two GSBR operated in alternating anoxic/aerobic or anaerobic/aerobic conditions for nutrient removal. Biochemical Engineering Journal, 2012, vol. 67, pp. 10-19. 10.1016/j.bej.2012.05.001 . hal-00878978

\section{HAL Id: hal-00878978 \\ https://hal.science/hal-00878978}

Submitted on 31 Oct 2013

HAL is a multi-disciplinary open access archive for the deposit and dissemination of scientific research documents, whether they are published or not. The documents may come from teaching and research institutions in France or abroad, or from public or private research centers.
L'archive ouverte pluridisciplinaire HAL, est destinée au dépôt et à la diffusion de documents scientifiques de niveau recherche, publiés ou non, émanant des établissements d'enseignement et de recherche français ou étrangers, des laboratoires publics ou privés. 


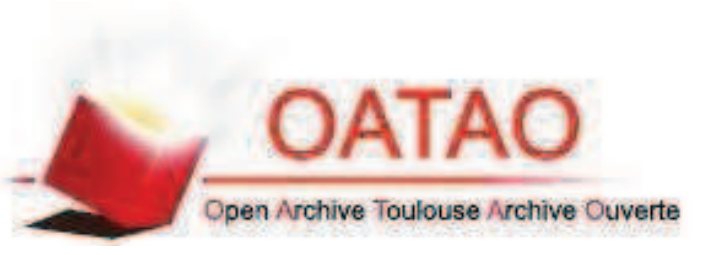

\section{Open Archive TOULOUSE Archive Ouverte (OATAO)}

OATAO is an open access repository that collects the work of Toulouse researchers and makes it freely available over the web where possible.

This is an author-deposited version published in : http://oatao.univ-toulouse.fr/ Eprints ID : 9981

To link to this article : DOI:10.1016/j.bej.2012.05.001

URL : http://dx.doi.org/10.1016/j.bej.2012.05.001

\section{To cite this version :}

Filali, Ahlem and Manas, Angela and Mercade, Myriam and Bessiere, Yolaine and Biscans, Béatrice and Sperandio, Mathieu Stability and performance of two GSBR operated in alternating anoxic/aerobic or anaerobic/aerobic conditions for nutrient removal. (2012) Biochemical Engineering Journal, vol. 67 . pp. 10-19. ISSN $1369-703 X$ 


\title{
Stability and performance of two GSBR operated in alternating anoxic/aerobic or anaerobic/aerobic conditions for nutrient removal
}

\author{
Ahlem Filali a,b,c,1, Angéla Mañas ${ }^{a, b, c, d, 1}$, Myriam Mercade $^{a, b, c}$, Yolaine Bessière ${ }^{a, b, c}$, Béatrice Biscans ${ }^{\mathrm{d}}$, \\ Mathieu Spérandio ${ }^{\mathrm{a}, \mathrm{b}, \mathrm{c}, *}$ \\ a Université de Toulouse; INSA, UPS, INP; LISBP, 135 Avenue de Rangueil, F-31077 Toulouse, France \\ b INRA, UMR792 Ingénierie des Systèmes Biologiques et des Procédés, F-31400 Toulouse, France \\ c CNRS, UMR5504, F-31400 Toulouse, France \\ d CNRS, Laboratoire de Génie Chimique, UMR5503; 4, allée Emile Monso BP 84234-F-31432 Toulouse Cedex 4, France
}

Keywords:

Aerobic granulation

Nitrification

Denitrification

Phosphorus

Filamentous

Precipitation

\begin{abstract}
A B S T R A C T
Two granular sludge sequencing batch reactors (GSBR) with alternating anoxic/aerobic (R1) and anaerobic/aerobic (R2) conditions were operated with a 4-carbon-source synthetic influent. The physical properties of the granular sludge were very good $\left(\mathrm{SVI} \approx 20 \mathrm{mLg}^{-1}\right)$ and high solid concentrations (up to $35 \mathrm{~g} \mathrm{~L}^{-1}$ ) were obtained in the bioreactor operated with a pre-anoxic phase with additional nitrate (R1). In contrast, performance and granule settleability were lower in R2 due to the development of filamentous heterotrophic bacteria on the surface of granules. These disturbances were linked to the fact that a fraction of COD remained during the aerobic phase, which was not stored during the anaerobic period. To stabilize a GSBR with a mixture of organic carbon sources, it is thus necessary to maximize the amount of substrate used during the non-aerated, anaerobic or anoxic, phase. Comparable phosphate removal efficiency was observed in both systems; enhanced biological P removal being greater in anaerobic/aerobic conditions, while the contribution of precipitation $(\mathrm{Ca}-\mathrm{P})$ was more significant in anoxic/aerobic conditions.
\end{abstract}

\section{Introduction}

The aerobic granular sludge process has been proposed as a promising approach to biological wastewater treatment [1]. Thanks to their dense structure, aerobic granules have very good settling ability that allows high biomass retention in the bioreactor. This enables the process to withstand high-strength wastewater and results in the biological reactor having a smaller volume than conventional activated sludge systems [2]. The size and density of the granules allow simultaneous nitrification, denitrification and phosphorus removal, SNDPR $[3,4]$ to be maintained. However, the operating conditions that improve the stability of the reactor's performance and the physical properties of aerobic granular sludge still need consideration. Instability and poorer properties of granular sludge have been reported for real sewage, for example, compared to the ideal results reported with purely acetate fed granules [5-7].

Various operating parameters have been identified that influence granule formation in aerobic systems. They include the

* Corresponding author at: Université de Toulouse, INSA, UPS, INP, LISBP, 135 Avenue de Rangueil, F-31077 Toulouse, France. Tel.: +33 561559755.

E-mail address: sperandio@insa-toulouse.fr (M. Spérandio).

1 These authors contributed equally to this work. aeration rate, substrate feeding mode, organic loading rate, and settling time [8-12]. In granular sludge sequencing batch reactors (GSBR), the aeration rate plays two major roles: firstly, it imposes the hydrodynamic conditions in the reactor and, secondly, it controls the oxygen mass transfer in the aggregates. High aeration rate has been shown to provide high shear force, which erodes the surface of granules; to stimulate bacterial strains to secrete more extracellular polymeric substances (EPS), thus enhancing structural integrity; to reduce substrate transfer resistance in the liquid boundary layer at the granule surface; and to provide sufficient oxygen for organic substrate degradation $[8,13]$. Various studies have demonstrated that a high aeration rate (expressed by the superficial air velocity SAV) accelerates the formation of stable aerobic granules. Beun et al. [14] showed that smooth, stable granules could be obtained only with an SAV above $2.0 \mathrm{~cm} \mathrm{~s}^{-1}$. Tay et al. [13] found that regular, rounder, compact aerobic granules could be formed only above a minimum aeration rate $\left(S A V=1.2 \mathrm{~cm} \mathrm{~s}^{-1}\right)$. Hence, the development of stable aerobic granules in pure aerobic systems is limited because of the high energy demand involved in aeration [15] and because efficient nitrogen and phosphorus removal requires the presence of anaerobic or anoxic and aerobic conditions [16].

Alternating anoxic/aerobic and anaerobic/aerobic conditions have both been reported to be helpful for granulation. Possible 


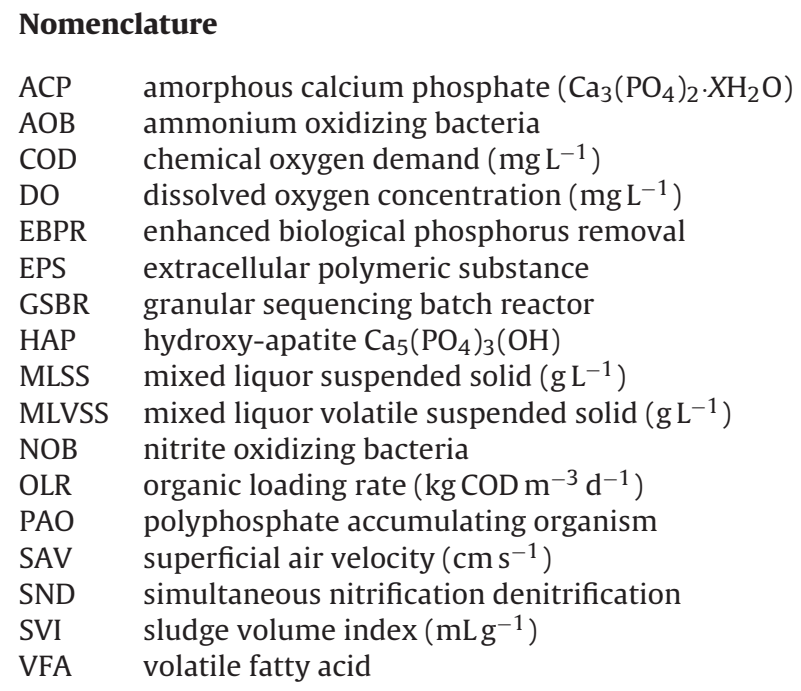

explanations for this are that conversion of readily biodegradable COD to internal stored biopolymers limits the substrate utilization rate during the aerobic phase [17] or that anoxic growth inside the granule improves aggregate density $[18,19]$. Another reason is that alternating non-aerated feast periods and aerated famine periods encourages the selection of slow-growing bacteria, which are supposed to be positive for the densification of bio-aggregates [9]. The work of Wan et al. [18] showed that the alternating anoxic feast and aerobic famine regimes allowed the formation of stable aerobic granules and simultaneous nitrification denitrification (SND) at a reduced air flow rate $\left(S A V=0.6 \mathrm{~cm} \mathrm{~s}^{-1}\right)$. On the other hand, the alternation of anaerobic and aerobic conditions has been widely reported to promote internal biopolymer storage and enhance biological phosphorus removal by polyphosphate-accumulating organisms [20,21].

Therefore, the aim of this study was to compare the effect of alternating anoxic/aerobic and anaerobic/aerobic conditions on the performance and stability of an aerobic granular sludge process for simultaneous carbon, nitrogen and phosphorus removal. For this purpose, two reactors were run in parallel. They were fed with a mixture of organic substrates and operated with a similar aeration rate. The first reactor (R1) was operated with alternating anoxic/aerobic conditions, the second one (R2) was operated with alternating anaerobic/aerobic conditions. Process performance and the microscale structure of granules were investigated for both reactors.

\section{Materials and methods}

\subsection{Reactor operating conditions}

The experimental set-up included two geometrically identical granular sequencing batch reactors (GSBR), each with a working volume of $17 \mathrm{~L}$ (internal diameter $=15 \mathrm{~cm}$, total height $=105 \mathrm{~cm}$, $H / D$ ratio $=7$ ). Both reactors were inoculated with the same concentration of a stabilized hybrid sludge (containing both flocs and granules) cultivated in alternating anoxic/aerobic conditions. The initial MLSS and MLVSS concentrations were $19.5 \mathrm{~g} \mathrm{~L}^{-1}$ and $13.1 \mathrm{~g} \mathrm{~L}^{-1}$ respectively. The initial SVI was $22 \mathrm{~mL} \mathrm{~g}_{\text {MLSS. }}^{-1}$ Reactor R1 was operated with alternating anoxic/aerobic conditions, whereas R2 was operated with alternating anaerobic/aerobic conditions. Each reactor was operated sequentially with a cycle time of $4 \mathrm{~h}$ including $15 \mathrm{~min}$ of feeding, $20 \mathrm{~min}$ of anoxic or anaerobic reaction (nitrogen gas injection); $145 \mathrm{~min}$ of aerobic reaction; $30 \mathrm{~min}$ of
Table 1

Operating conditions of both reactors.

\begin{tabular}{|c|c|c|}
\hline Parameter & $\mathrm{R} 1$ & $\mathrm{R} 2$ \\
\hline Volumetric exchange ratio (\%) & \multicolumn{2}{|c|}{47} \\
\hline Hydraulic retention time $(\mathrm{h})$ & \multicolumn{2}{|c|}{8.5} \\
\hline Organic loading rate $\left(\mathrm{kg} \mathrm{COD} \mathrm{m}^{-3} \mathrm{~d}^{-1}\right)$ & \multicolumn{2}{|c|}{2.8} \\
\hline Ammonia loading rate $\left(\mathrm{kg} \mathrm{N}-\mathrm{NH}_{4} \mathrm{~m}^{-3} \mathrm{~d}^{-1}\right)$ & \multicolumn{2}{|c|}{0.14} \\
\hline Nitrate loading rate $\left(\mathrm{kg} \mathrm{N}-\mathrm{NO}_{3} \mathrm{~m}^{-3} \mathrm{~d}^{-1}\right)$ & 0.28 & 0 \\
\hline Phosphorus loading rate $\left(\mathrm{kg} \mathrm{P}-\mathrm{PO}_{4} \mathrm{~m}^{-3} \mathrm{~d}^{-1}\right)$ & \multicolumn{2}{|c|}{0.08} \\
\hline Superficial upflow velocity of $\mathrm{N}_{2}\left(\mathrm{~cm} \mathrm{~s}^{-1}\right)$ & $1.1 \pm 0.1$ & $0.6 \pm 0.1$ \\
\hline Superficial upflow velocity of air $\left(\mathrm{cm} \mathrm{s}^{-1}\right)$ & \multirow{2}{*}{\multicolumn{2}{|c|}{$\begin{array}{c}1.0 \pm 0.1 \\
20 \pm 2\end{array}$}} \\
\hline Temperature $\left({ }^{\circ} \mathrm{C}\right)$ & & \\
\hline $\mathrm{pH}$ (not regulated) & $7.5-9.2$ & $7.2-8.5$ \\
\hline
\end{tabular}

settling and $30 \mathrm{~min}$ of discharge (with a volumetric exchange ratio of $47 \%$ ). The aeration rate was similar in both reactors, with a superficial air upflow velocity (SAV) of $1.0 \pm 0.1 \mathrm{~cm} \mathrm{~s}^{-1}$. Both reactors were fed at the bottom of the column when aeration was stopped (static fill). The feed consisted of a synthetic substrate [18] having the following composition: COD of $1000 \mathrm{mg} \mathrm{L}^{-1}(25 \%$ contribution each of glucose, acetate, propionic acid and ethanol), $\left[\mathrm{PO}_{4}{ }^{3-}\right]=30 \mathrm{mg} \mathrm{PL}^{-1}, \quad\left[\mathrm{Ca}^{2+}\right]=46 \mathrm{mg} \mathrm{L}^{-1}, \quad\left[\mathrm{HCO}_{3}{ }^{-}\right]=100 \mathrm{mg} \mathrm{L}^{-1}$, $\left[\mathrm{MgSO}_{4} \cdot 7 \mathrm{H}_{2} \mathrm{O}\right]=12 \mathrm{mg} \mathrm{L}^{-1},\left[\mathrm{NH}_{4}{ }^{+}\right]=50 \mathrm{mgNL}^{-1}$. A COD $/ \mathrm{N}-\mathrm{NH}_{4}{ }^{+}$ ratio of 20 was maintained. Nitrate was dosed in $\mathrm{R} 1$ in order to maintain anoxic conditions after feeding $\left(\left[\mathrm{NO}_{3}{ }^{-}\right]=100 \mathrm{mgN} \mathrm{L}^{-1}\right)$. The $\mathrm{pH}$ probe and $\mathrm{DO}$ probe were installed online and the data were acquired by the computer every $30 \mathrm{~s}$. pH fluctuated naturally during a reactor cycle, from 7.5 to 9.2 in $\mathrm{R} 1$ and from 7.2 to 8.5 in R2. The temperature was maintained at $20 \pm 2{ }^{\circ} \mathrm{C}$ with a water jacket. The reactor performance was monitored through weekly cycle studies, in which samples were analysed at regular intervals during an SBAR cycle. Table 1 summarizes the main operating conditions of the two reactors.

Due to annual closure, the supply of influent to the reactors was interrupted for two consecutive weeks and the cycle of operation was modified: the new 2-h cycle consisted of 15 min aeration and $105 \mathrm{~min}$ settling. This period (from day 105 to day 120) is referred to as the "starvation period".

\subsection{Analytical characterization of the liquid and solid phases}

Analyses were conducted according to standard methods (AFNOR) [22]: COD (NFT 90-101), MLSS (NFT 90-105) and MLVSS (NFT 90-106). $\mathrm{NO}_{2}{ }^{-}, \mathrm{NO}_{3}{ }^{-}, \mathrm{PO}_{4}{ }^{3-}, \mathrm{NH}_{4}{ }^{+}, \mathrm{Ca}^{2+}, \mathrm{K}^{+}, \mathrm{Mg}^{2+}$ concentrations were analysed by ion chromatography (IC25, 2003, DIONEX, USA) with prior filtering of the samples through a $0.2 \mu \mathrm{m}$ poresize acetate filter. The sludge volume index (SVI) was measured in the reactor after 30 min of settling and showed less than $\pm 10 \%$ of difference relative to the standard procedure in a graduated test tube. Microscopic observations of sludge samples were made with a Biomed-Leitz ${ }^{\circledR}$ binocular photonic microscope. Particle size distribution was measured with a Malvern 2000 Mastersizer $^{\circledR}$ analyzer and with statistical image processing.

The proportion of granules by mass and by volume was estimated using Eqs. (1) and (2) respectively:

Percentage of granules by mass $=\frac{\text { MLSS }_{\text {granule }} \times 100}{M_{\text {LSS }} \text { hybrid sludge }}$

Percentage of granules by volume $=\frac{V_{\text {granule }} \times 100}{V_{\text {hybrid sludge }}}$

where MLSS $_{\text {granule }}$ and MLSS $S_{\text {hybrid sludge }}$ are the mixed liquor suspend solids in granules and hybrid sludge respectively. In order to assess the MLSS of granules, sieving at $315 \mu \mathrm{m}$ was performed as described in Filali et al. [23]. $V_{\text {granule }}$ and $V_{\text {hybrid sludge }}$ represent the apparent volume of granules and hybrid sludge, respectively, in the reactor after $30 \mathrm{~min}$ of settling. 

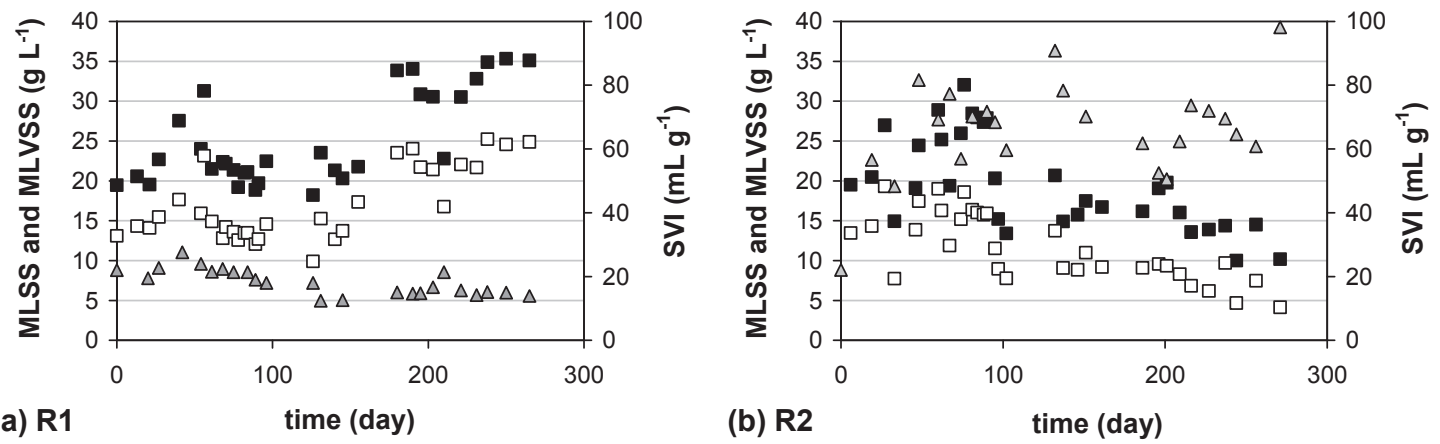

Fig. 1. Evolution of suspended solids during the running period of the reactors ( $\boldsymbol{\square}$ ) MLSS, ( $\square$ ) MLVSS and ( $\mathbf{A}$ ) SVI in R1 (a) and R2 (b).

\subsection{Microbial characterization}

\subsubsection{FISH probing}

Floc and granule samples were fixed as described in Filali et al. [23]. Filamentous bacteria that had developed at the surface of granules were detached with a sterile scalpel and subjected to the same procedure as the flocs. In situ hybridization was performed according to the standard hybridization protocol [24]. The fluorescently labelled oligonucleotide probes used were as follows: Nso190 and Nso1225 (labelled with FITC) for AOB [25], Nit3 (labelled with Cy3) for Nitrobacter spp. [26] and Ntspa662 (labelled with Cy3) for Nitrospira spp. [27]. DAPI (4',6diamidino-2-phenylindole, dihydrochloride) was used to stain all the DNA-containing organisms. To avoid non-specific staining, unlabelled competitor probes CNit3 and CNtspa662 were added with equimolar amounts of Nit3 and Ntspa662, respectively.

Fluorescent in situ hybridization images were collected with a confocal laser scanning microscope (LEICA SP2, DMRXA2, Germany) using an argon laser $(488 \mathrm{~nm})$ for FITC excitation, a helium-neon laser for Cy3 $(543 \mathrm{~nm})$ and a diode laser for DAPI $(405 \mathrm{~nm})$. Their fluorescence was detected at $498-550 \mathrm{~nm}$, $571-630 \mathrm{~nm}$ or $415-450 \mathrm{~nm}$ respectively. To obtain images of half-granule sections, 10-20 (depending on the size of the granule) overlapping, consecutive images of $1024 \times 1024$ pixels were acquired using a $16 \times$ oil objective. The final composite image of the granule section was then reconstructed from all the individual images collected using INKSCAPE open source scalable vector graphics. Images of bacterial clusters were acquired using a $100 \times$ oil objective.

\subsubsection{PHB staining}

Poly-hydroxy butyrate (PHB) staining was carried out using a protocol adapted from Pandolfi et al. [28]. Samples were cut to $100-\mu \mathrm{m}$ thickness and spread over a glass plate. Once air-dried, the samples were placed in a solution of Sudan black for $5 \mathrm{~min}$, then rinsed with ethanol at 70 vol.\% and dried. Safranin was dropped on to the dry samples, covering them completely, and left in contact for $5 \mathrm{~s}$. The samples were dried again, then rinsed with distilled water and observed with an optical microscope. Safranin was used to show up the cytoplasmic membranes in red (bacterial cells) whereas Sudan black stained the PHB inclusions blue.

\section{Results and discussion}

\subsection{Performance stability}

Figs. 1 and 2 show the evolution of solid concentration and the removal efficiencies of reactors $\mathrm{R} 1$ and $\mathrm{R} 2$, respectively, during the whole operation. Both reactors were started with similar seeds and showed the same suspended solids concentration, i.e. $19.5 \mathrm{~g} \mathrm{TSS} \mathrm{L}^{-1}$ and $13.1 \mathrm{~g} \mathrm{VSS} \mathrm{L}^{-1}$, together with very good settling properties (SVI was initially close to $22 \mathrm{mLg}^{-1}$ ).

After about 50 days of running and up to the end of the study (300 days), performance was very stable in the anoxic/aerobic reactor (R1). The removal of soluble COD, ammonia and total nitrogen were $96 \%, 100 \%$ and $89 \%$, respectively. The removal of phosphorous gradually increased and stabilized at $45 \%$. MLSS and MLVSS first stabilized around $21.0 \pm 1.5 \mathrm{~g} \mathrm{TSS} \mathrm{L}^{-1}$ and $13.8 \pm 1.2 \mathrm{~g} \mathrm{VSS} \mathrm{L}^{-1}$, respectively, and then gradually accumulated in the reactor up to $35 \mathrm{~g} \mathrm{TSS} \mathrm{L}^{-1}$ and $25 \mathrm{~g} \mathrm{VSS} \mathrm{L}^{-1}$, with a VSS/TSS ratio of $65-70 \%$. The accumulation of suspended solids was also associated with a decrease of SVI $\left(16 \pm 2 \mathrm{mLg}^{-1}\right)$. Performances were stable and it was interesting to observe that, after a starvation period of 15 days (starting on day 105) during which it was not fed, the reactor was easily started again and it took less than one week for removal performances to be fully recovered, underlining the robustness of the granules from R1.

In the second reactor (R2), performance initially declined and neither the sludge concentration nor the reactor performances were fully stabilized at any time during the study. The MLSS concentration initially increased, reaching $32 \mathrm{~g} \mathrm{~L}^{-1}$, but then progressively decreased to less than $10 \mathrm{gL}^{-1}$. The sludge volume index (SVI) fluctuated around $70 \pm 15 \mathrm{mLg}^{-1}$ during the first 100 days and then increased to $90 \mathrm{mLg}^{-1}$. The COD removal efficiency varied between 90 and 95\%, whereas ammonia and total nitrogen removal fluctuated between $60 \%$ and $100 \%$ (mean values of $86 \%$ and $84 \%$ respectively). Phosphorus removal oscillated between 10 and 80\% with a mean efficiency of $42 \%$.

\subsection{Evolution of sludge properties}

As both reactors were initially seeded with a mixture of granules and flocs, the evolution of the percentage of granules in the two reactors was an interesting indicator of sludge properties (Fig. 3). A slight enrichment in granules was observed in R1, the granule percentage increasing from 60 to $80 \%$ of the total volume and constituting more than $90 \%$ of the mass. Granule size also progressively increased (from 1 to $3 \mathrm{~mm}$ ). Concomitantly, a decreasing proportion of flocs was observed throughout the study.

In contrast, in R2, sludge properties evolved differently. From day 33, an increase of granule fraction by mass was observed, together with a decrease of their fraction by volume, which clearly indicates a strong modification of the aggregate properties and floc washout. This can be explained by the fact that granules rapidly became bigger (from 1 to $4 \mathrm{~mm}$ in diameter) due to a filamentous (fluffy) growth on the surface. As granular sludge occupied a larger volume in the reactor after settling, flocs were washed out and the granule percentage initially increased. Concomitantly, filamentous suspended growth was also observed and the flocs thus generated, even though they contributed little to the total mass of sludge, were 

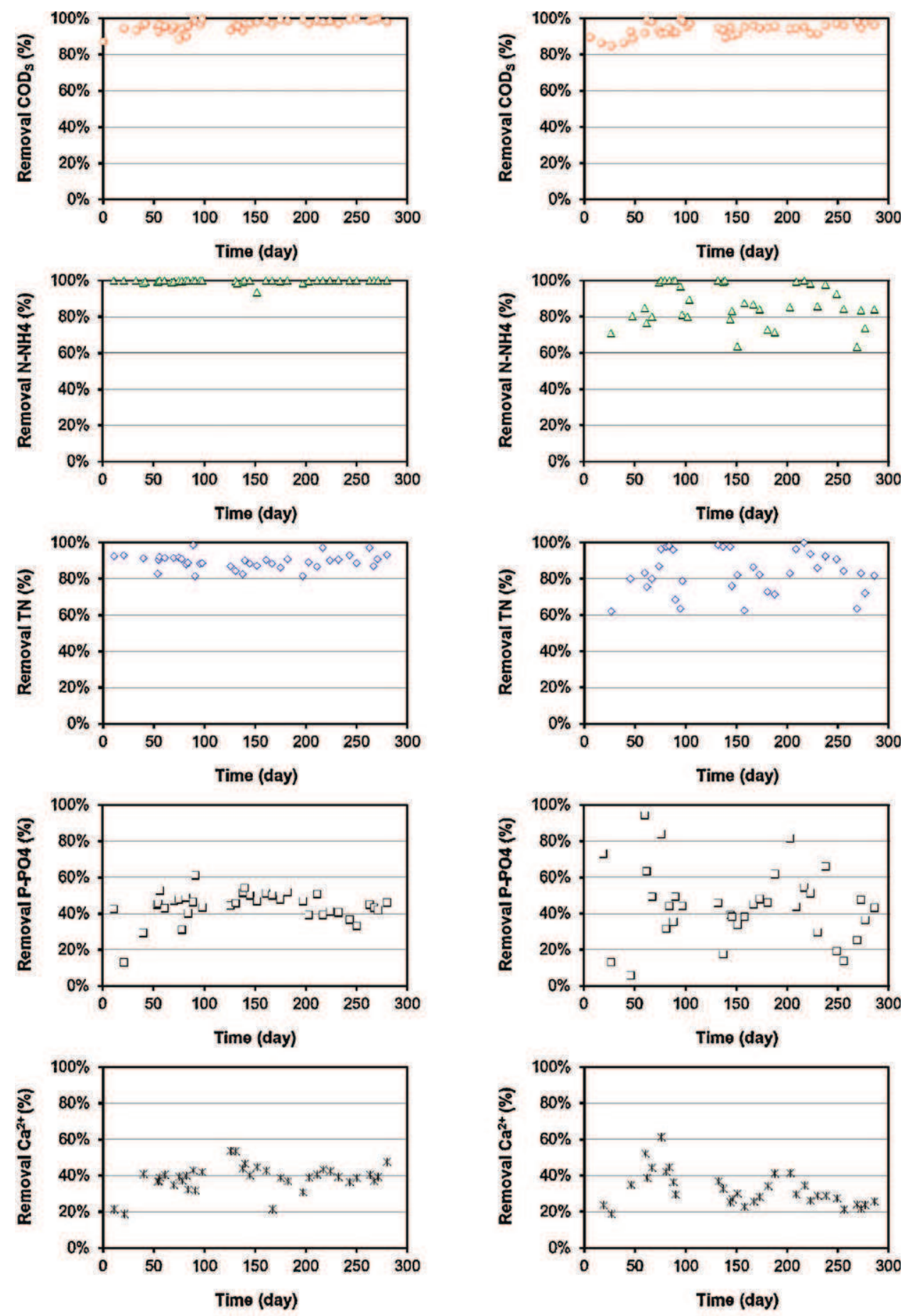

(a)R1

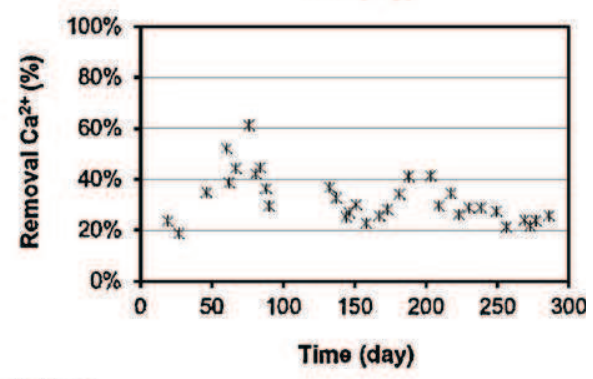

(b) R2

Fig. 2. Evolution of removal efficiencies of $(O) \mathrm{COD},(\triangle) \mathrm{N}-\mathrm{NH}_{4},(\diamond) \mathrm{TN},(\square){\mathrm{P}-\mathrm{PO}_{4}}_{4}$ and $(\Psi) \mathrm{Ca}^{2+}$ in $\mathrm{R} 1$ (a) and $\mathrm{R} 2(\mathrm{~b})$.

likely to occupy a large volume and to considerably affect sludge settling as the SVI rose to $70 \pm 15 \mathrm{mLg}^{-1}$.

Fig. 4 shows the correlation between the MLSS concentration and the percentage of granules in both reactors. It indicates that the MLSS globally increased with the proportion of the volume occupied by the granules and the diminution of suspended biomass growth.

From the microscope observations (Fig. 5), it can be seen that granules from R1 presented a smooth round surface similar to the granules initially seeded (Fig. 5a). In contrast, as already mentioned, filamentous bacteria grew out from the surface of R2 granules
(Fig. 5b), and this filamentous layer seemed to cause oxygen transfer limitation as indicated by the release of gas bubbles (Fig. 5e). As suggested by Mosquera-Corral et al. [15], long-term anaerobic conditions inside the granule could lead to growth of methanogenic bacteria.

With time, the surface of some of the mature granules from both reactors became cracked and broken, revealing a stronger core (Figs. 5c and d). The strength of the internal part of the granules was probably explained by mineral precipitation as demonstrated by Mañas et al. [29]. Whereas, in R1, the loss of efficiency due to mature granule disintegration seemed to be compensated by the 

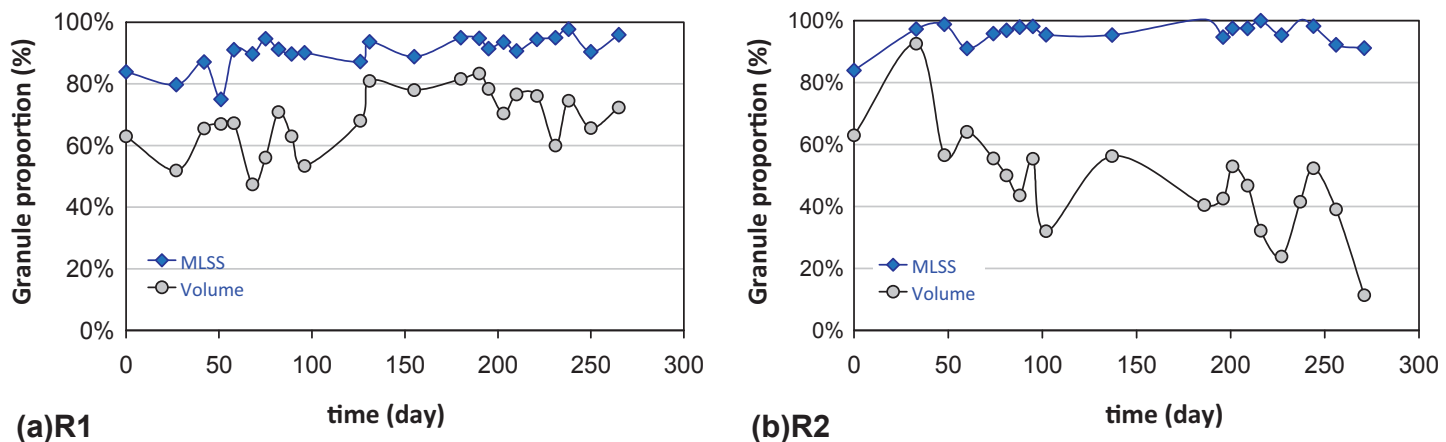

Fig. 3. Evolution of the proportion of granules in MLSS and in volume of the hybrid sludge in both reactors.
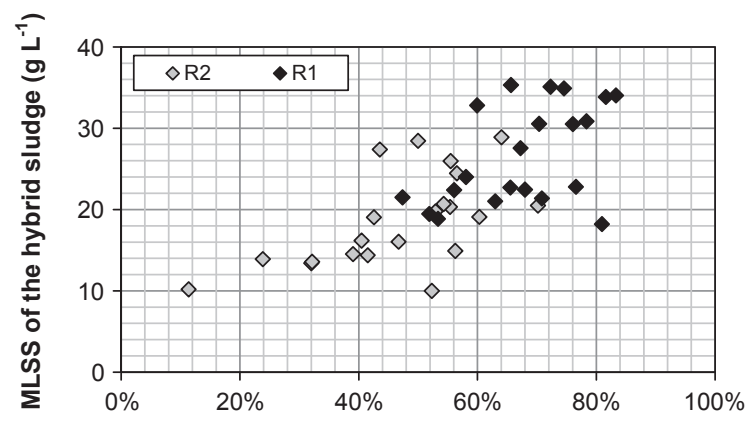

Granule proportion in volume (\%)

Fig. 4. Relationship between the MLSS concentration and the granule percentage by volume.

birth of small new ones, granules from R2 progressively lost their density but no new small granules seemed to be generated in this reactor.

\subsection{Nitrogen removal}

\subsubsection{Kinetics}

Kinetic analyses were performed during the batch cycle to assess COD, nitrogen and phosphorus removal (Fig. 6).
During the anoxic phase in reactor $\mathrm{R} 1, \mathrm{COD}$ and nitrate were rapidly depleted. Denitrification occurred at a rate of $350 \mathrm{mgN} \mathrm{L}^{-1} \mathrm{~h}^{-1}$, and nitrite concentration increased, transiently reaching $5 \mathrm{mgN} \mathrm{L}^{-1}$. Ammonium was depleted after $1.5 \mathrm{~h}$ during the aerobic phase, $46 \%$ being removed by heterotrophic assimilation during the anoxic period and $54 \%$ aerobically at a rate (AUR) of $8.9 \mathrm{mgN} \mathrm{L}^{-1} \mathrm{~h}^{-1}$. Nitrite and nitrate accumulated, reaching $6 \mathrm{mgN} \mathrm{L}^{-1}$ and $14 \mathrm{mgN} \mathrm{L}^{-1}$ respectively. DO was first stabilized at $5 \mathrm{mg} \mathrm{L}^{-1}$ during nitrification and then increased to $6.3 \mathrm{mg} \mathrm{L}^{-1}$ after ammonia depletion. The stable profile of TN during the aerobic period indicates that simultaneous nitrification denitrification did not occur significantly in this reactor. This could be explained by DO not being low enough and insufficient organic carbon being stored during the anoxic (feast) phase to allow denitrification in the granules during the aerated phase.

In reactor $\mathrm{R} 2$, during the non-aerated phase, the COD decreased by $134 \mathrm{mg} \mathrm{L}^{-1}$, which corresponds to $25 \%$ of the COD fed to the system, and reached a plateau at about $400 \mathrm{mg} \mathrm{L}^{-1}$. During the aerated phase, the oxygen profile reached a first plateau at $2.5 \mathrm{mg} \mathrm{L}^{-1}$, a second plateau at $4 \mathrm{mg} \mathrm{L}^{-1}$, and then increased to $6.3 \mathrm{mg} \mathrm{L}^{-1}$ after $85 \%$ of the COD had been removed. The $\mathrm{pH}$ increase from 7.2 to 8.2 during the first oxygen plateau indicated probable consumption of VFA and stripping of $\mathrm{CO}_{2}$. During the second plateau, ammonium was progressively consumed but nitrate and nitrite concentration remained negligible. Concomitantly, the presence of AOB was demonstrated by FISH analysis in granules from R2 whereas NOB were not detected (see Section 3.3.2). In addition, the nitrification
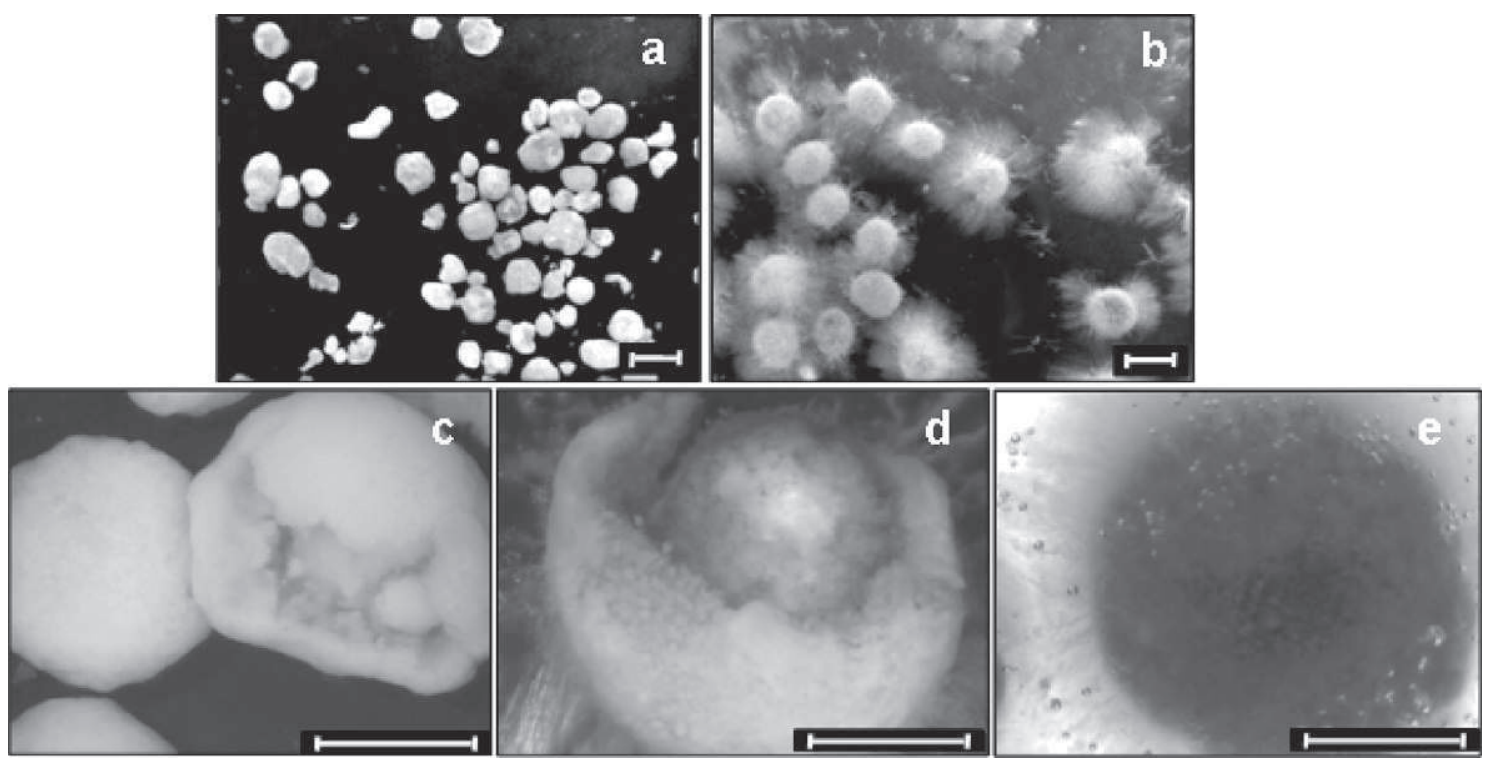

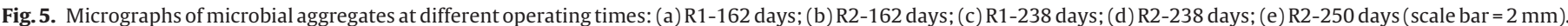



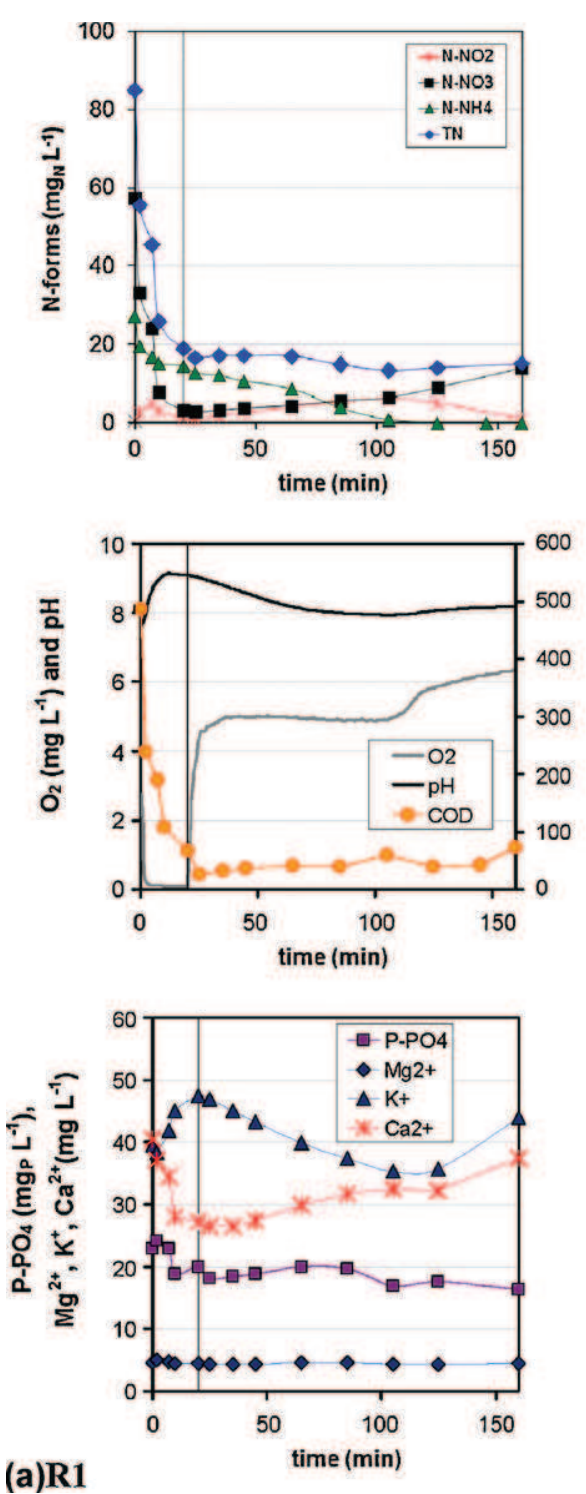
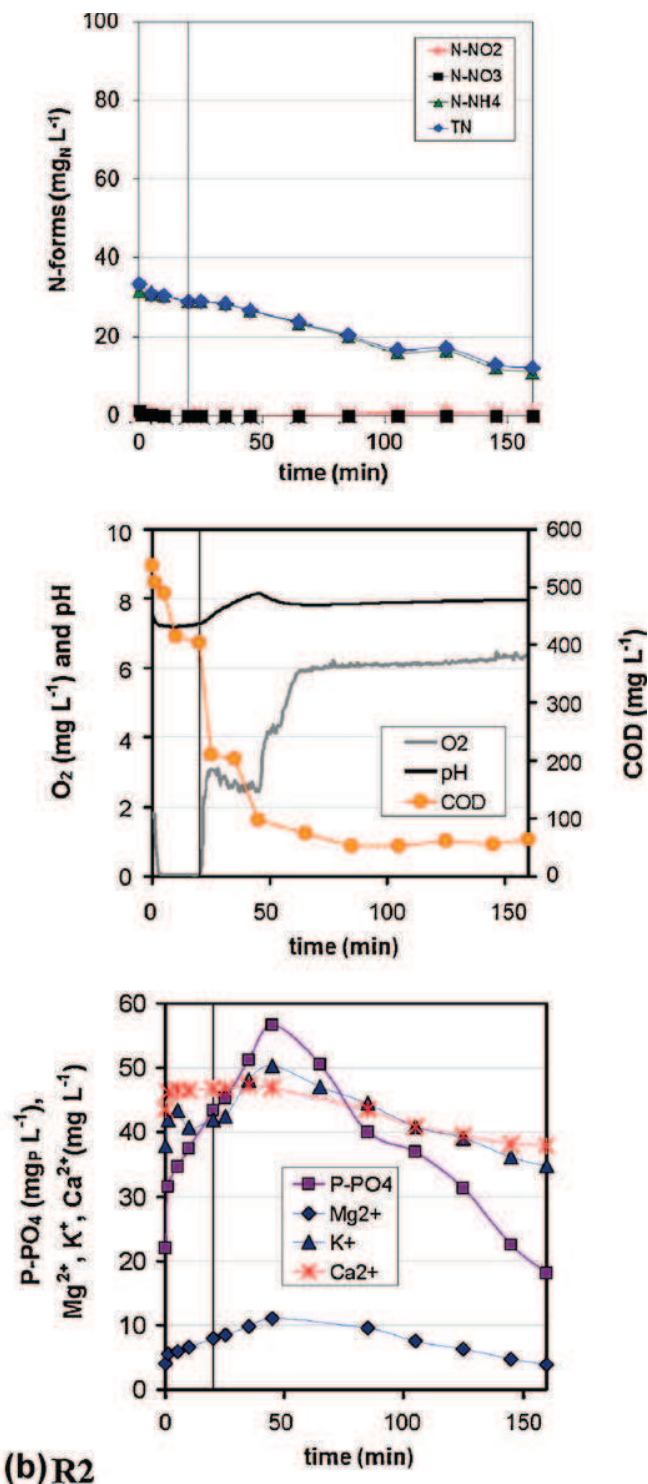

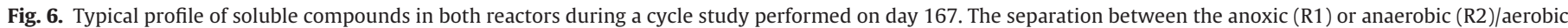
phases is depicted by a vertical line.

rate was also measured in batch respirometric tests with granular sludge collected from R2 at the end of the aerobic phase (at DO of $5 \mathrm{mg} \mathrm{L}^{-1}$, with ammonia addition of $10 \mathrm{mgN} \mathrm{L}^{-1}$, without addition of organic carbon). AUR was $0.99 \mathrm{mgN} \mathrm{g}^{-1} \mathrm{VSS} \mathrm{h}^{-1}$, no nitrate was observed and nitrite accumulated at a rate of $0.57 \mathrm{mgN} \mathrm{g}^{-1} \mathrm{VSS} \mathrm{h}^{-1}$. These observations encourage us to think that ammonium was simultaneously removed by heterotrophic assimilation and SND during the aerobic phase in the reactor R2. Due to heterotrophic bacteria respiration and growth on storage compounds, the nitrite produced by AOB was fully consumed and some of the ammonia was also assimilated. This is in accordance with the presence of $\mathrm{AOB}$ and the absence of NOB in these granules. Despite the fact that the AUR in R2 was close to that observed in R1 $\left(8.3 \mathrm{mgN} \mathrm{L}^{-1} \mathrm{~h}^{-1}\right)$, the ammonium was not depleted at the end of the cycle because ammonium started to be nitrified after the COD was depleted. Before that, the oxygen level in the granules was probably too low because of high heterotrophic activity. The final concentration of ammonium in the effluent was $11 \mathrm{mgN} \mathrm{L}^{-1}$ but varied greatly from one cycle to another, leading to unstable ammonium removal efficiency (Fig. 2b). This critical instability of nitrification was due to the small proportion of ammonia assimilated during the non-aerated phase and to the strong competition between heterotrophic and autotrophic bacteria for oxygen during the aerobic phase.

\subsubsection{Spatial distribution of nitrifiers}

FISH analysis was performed to assess the microscale structure of granules and the localization of nitrifying bacteria. Fig. 7 shows the images of granules from R1 ( $a, c$ and d) and R2 (b and g), together with suspended biomass from R1 (e) and filamentous bacteria from R2 (f). DAPI staining (blue) indicated the presence of heterotrophic bacteria in the granules. Fig. 7b confirms that granules from R2 were much more irregular than those of R1 (a).

In the first reactor, the localization of nitrifiers in the granules did not change significantly during the run. The image of a half-granule section (Fig. 7a) shows that AOB (magenta) were distributed throughout the granule and, in particular, near large channels and internal voids. The NOB (yellow) were found to be located in deeper layers of the granule (about $250 \mu \mathrm{m}$ from the surface) and profusely around the internal core of the granule. As observed in previous studies [30,31], channels and internal voids may play a key role in the transport of oxygen and substrate, which would explain this localization. AOB were found to form dense 

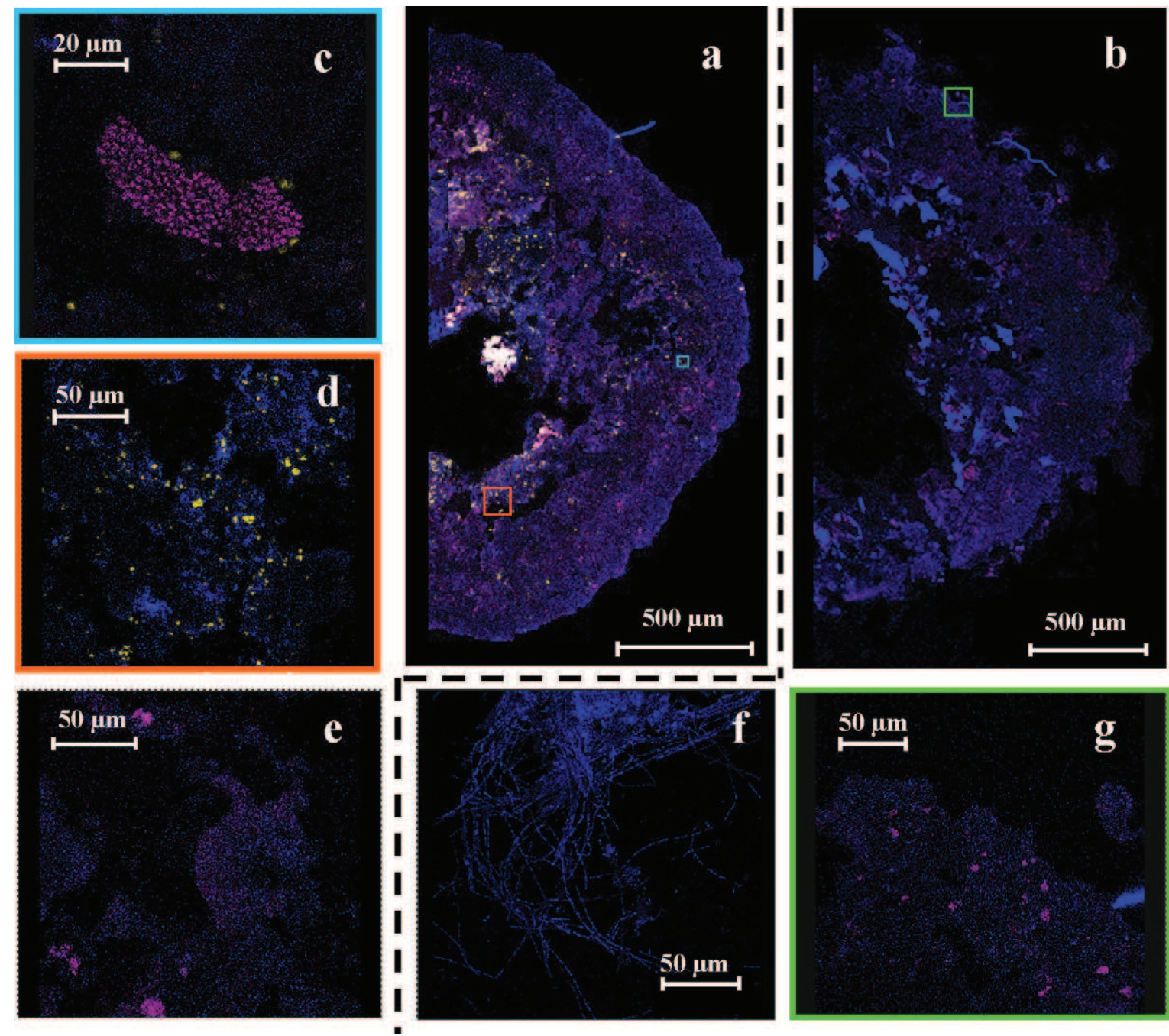

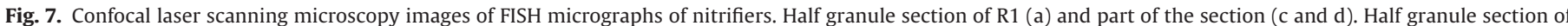

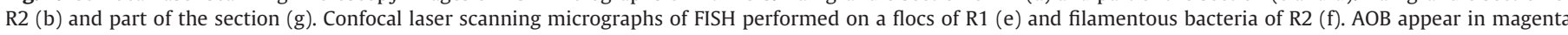

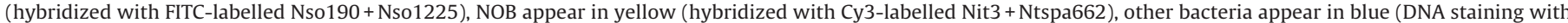
DAPI). (For interpretation of the references to colour in this figure legend, the reader is referred to the web version of the article.)

bacterial clusters with sizes ranging from 10 to $50 \mu \mathrm{m}$ (Fig. 7c). NOB clusters were dense and small, their size rarely exceeding $10 \mu \mathrm{m}$ (Fig. 7d). Hybridization of samples of flocs from R1 was also performed (Fig. 7e). AOB were frequently observed in floc samples, forming large, dense clusters, whereas very few NOB were observed.

The spatial distribution of nitrifiers in a half-granule section of R2 (observed on day 227) is reported in Fig. 7b. The distribution of AOB in R2 granules was less extensive than the distribution observed in R1. AOB were located only in the outermost $250 \mu \mathrm{m}$ of the R2 granules. Their distribution was not homogeneous through that layer. AOB clusters colonized some large parts of the aggregate and were totally absent from others. In addition, many of them were found to develop at the surface of the granule. Fig. $7 \mathrm{~g}$ shows typical dense clusters of $A O B$ that have developed near the surface of the granule. In contrast to R1 clusters, AOB clusters in R2 were relatively small and rarely exceeded a size of $20 \mu \mathrm{m}$. The hybridization of NOB with the oligonucleotides Nit3 and Ntspa662 gave a low signal similar to background noise and no typical bacterial clusters could be identified (with a magnification $100 \times$ ). It was thus observed that NOB were not significantly present in granules from R2. The hybridization of samples of flocs and filamentous bacteria that had developed at the surface of the granules (Fig. 7f) from R2 indicated that suspended biomass did not contain nitrifying bacteria, be they AOB or NOB (result not shown).

The FISH results corroborate the kinetic assessment that neither nitrite nor nitrate was accumulated (Section 3.3.1), indicating that nitrifiers are difficult to maintain in an anaerobic/aerobic system because of strong competition with heterotrophs for oxygen and space. Furthermore, the absence of NOB in the reactor confirms that SND favours the direct denitrification of nitrite in the core of granules, which progressively limits the development of NOB.

\subsection{Phosphorus removal}

\subsubsection{Kinetic assessment}

Kinetics assessed over a reactor cycle (Fig. 6) showed the different processes involved in phosphorus removal. In R1 (Fig. 6a), a rapid decrease of $\mathrm{PO}_{4}$ was observed during the anoxic phase concomitant with a $\mathrm{pH}$ increase due to denitrification. It has been demonstrated previously [29] that calcium phosphate precipitation is responsible for this phenomenon. There was no apparent phosphate release in R1 during the unaerated period. This observation seems logical because, usually, a pre-anaerobic (rather than anoxic) period is used to induce biological phosphate removal. Here, nitrate was preferentially used by ordinary heterotrophic biomass for 

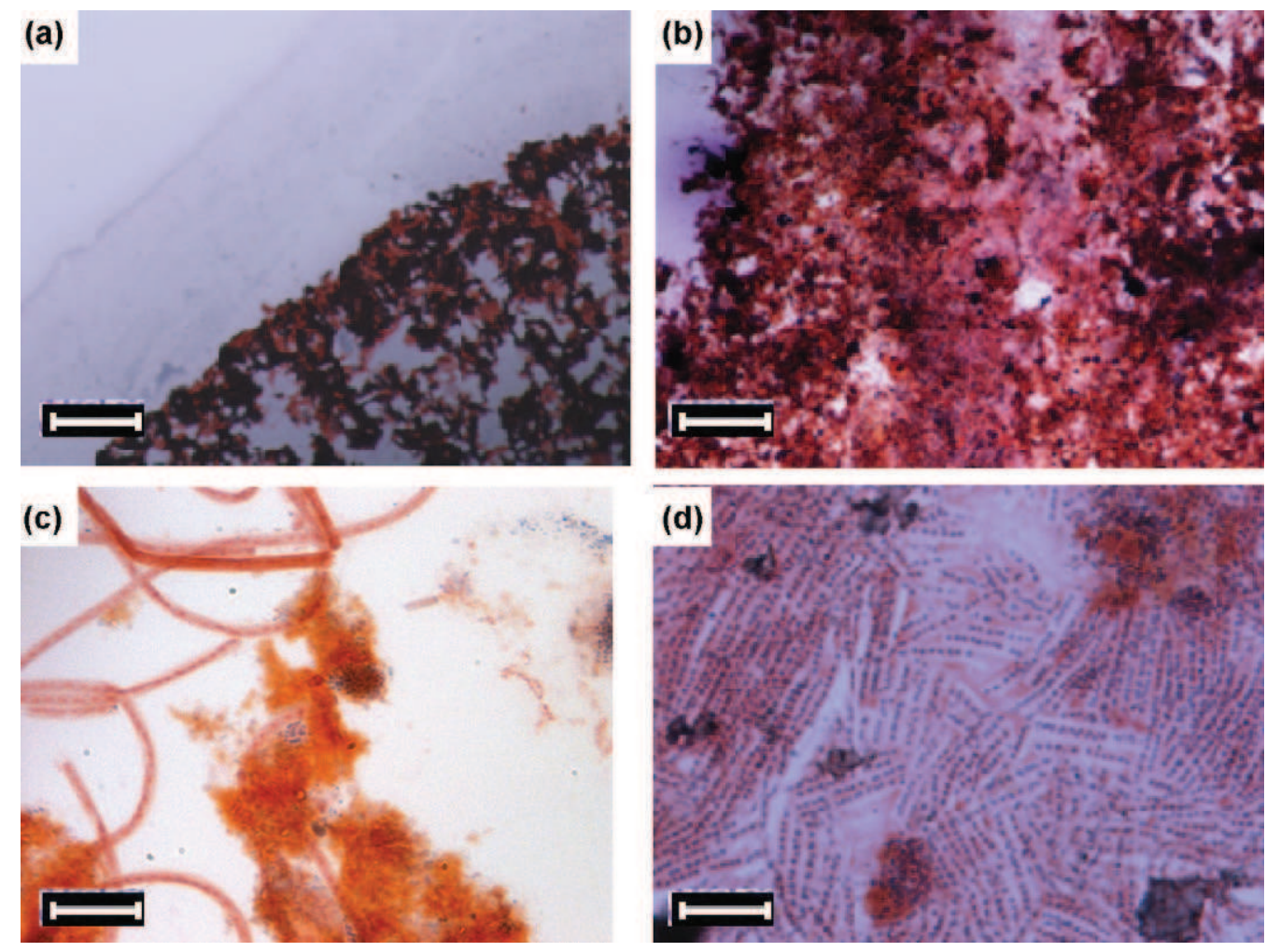

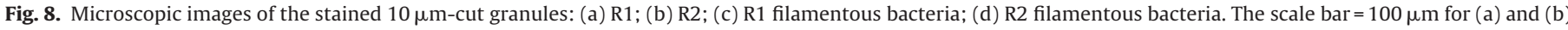

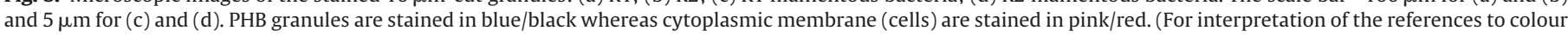
in this figure legend, the reader is referred to the web version of the article.)

substrate oxidation. However, a little polyphosphate-accumulating organism (PAO) activity can nevertheless be suspected in reactor R1 for two reasons: first, the potassium concentration showed a profile (release and uptake) typically explained by its inclusion in a polyphosphate structure and, second, specific anaerobic batch tests performed with granular sludge from R1 (with acetate as the sole carbon source, without additional calcium or magnesium, at a $\mathrm{pH}$ that avoided precipitation) showed a $\mathrm{P}$ release rate of $2.18 \mathrm{mgPg}^{-1} \mathrm{MLVSS} \mathrm{h}^{-1}$, which is comparable to data obtained with sludge from the EBPR process [32]. The presence of PAO in reactor R1 could appear surprising as this reactor was operated mainly in anoxic/aerobic conditions. However it should be noted that nitrate and nitrite were depleted after 10-15 min and the end of the period was anaerobic. Moreover, due to the density of granules, an anaerobic zone could be found inside them, even though nitrate and nitrite were measured in the bulk. Thus, anaerobic P release and uptake was possibly masked by $P$ precipitation in the GSBR reactor R1. Finally, despite the possible presence of PAO, the contribution of biological reactions to P removal was probably low compared to precipitation (see Section 3.4.3).

As shown by Fig. 6b, significant anaerobic release of $\mathrm{PO}_{4}$ took place in the second reactor (R2). This release continued during the first oxygen step in the aerobic phase $\left(\mathrm{DO}=2.5 \mathrm{mg} \mathrm{L}^{-1}\right)$, which means that some of the PAO were still converting substrate(VFA) to internal polymers (as suggested by the concomitant $\mathrm{pH}$ increase). This was possibly due to the presence of anaerobic zones in the granule during this phase as oxygen uptake rate was high until COD was depleted in the reactor. In the kinetics presented, the final phosphate concentration is similar to that observed in reactor R1. However, depending on the cycle, phosphate removal was unstable in R2. This may have been due to significant variability in the heterotrophic activity at the beginning of the aerobic phase (Fig. 2b), which would influence P uptake rate. Another explanation could be the heterogeneous sludge wastage imposed in the granular sludge process. Sludge was naturally wasted via loss of suspended solids after biomass detachment from granules. This means that it was difficult to set a given retention time for bacteria as in the conventional EBPR processes. Here, apparent mean SRT varied from 5 to 15 days based on the suspended solids mass balance. However, local SRTs in the granules were probably higher. The biological P removal would probably have been more stable if a regular wastage of granules had been performed. This assumption needs to be confirmed in future work.

\subsubsection{PHB staining}

Bacterial carbon storage was analysed using the PHB staining technique in both reactors. Fig. 8a and b shows granule sections, one from $\mathrm{R} 1$ and one from R2, obtained from samples collected at the beginning of the aerobic phase (PHB granules are stained blue/black whereas cytoplasmic membranes (cells) are stained pink/red).

PHB was distributed in a thin layer in the peripheral zone of the granules and close to internal voids and channels in the internal part of the granules. Comparison of samples from the two reactors indicated that, in the granules from R2, PHB was more present in the peripheral zone, including the filamentous bacterial outgrowth (Fig. 8d). This confirms that high heterotrophic activity and carbon storage occurred at the surface whereas growth/storage in the centre became difficult, probably because of diffusion limitation in the granules from R2.

\subsubsection{Phosphate precipitation contribution}

The contribution of precipitation to overall $\mathrm{P}$ removal can be estimated from calcium behaviour. Calcium is not significantly implicated in the biological formation of polyphosphate [33] but precipitates mainly in the form of calcium phosphate as demonstrated by Mañas et al. [29]. From thermodynamic analysis, 
amorphous calcium phosphate (ACP) and hydroxy-apatite (HAP) were the most probable minerals. X-ray diffraction patterns (not shown) were compared for granules from R1 and R2, and showed that the most significant mineral was $\mathrm{HAPCa}_{5}\left(\mathrm{PO}_{4}\right)_{3}(\mathrm{OH})$ although, in the case of the $\mathrm{R} 1$ spectrum, a small amount of whitlockite $\left(\mathrm{Ca}_{18} \mathrm{Mg}_{2} \mathrm{H}_{2}\left(\mathrm{PO}_{4}\right)_{14}\right)$ was also indicated.

Precipitation was mainly controlled by $\mathrm{pH}$ in the bioreactors. Calcium concentration decreased in R1 during the anoxic phase when $\mathrm{pH}$ reached the highest values, close to 9 , and calcium was progressively released during the aerobic period as $\mathrm{pH}$ decreased with nitrification (Fig. 6a). The calcium profile in R2 (Fig. 6b) remained stable during the anaerobic period with stable $\mathrm{pH}$ around 7.5 but decreased during the aerobic phase as a consequence of $\mathrm{pH}$ increasing to 8 . The total $\mathrm{Ca}^{2+}$ removal was $40 \%$ in reactor 1 (see Fig. 2) whereas it progressively decreased to $20 \%$ in reactor R2 (more unstable). This tends to show that calcium phosphate precipitation was greater in the first reactor than in the second, which is consistent with the fact that mean $\mathrm{pH}$ was higher in the first reactor due to more intense denitrification. More details on the relation between $\mathrm{pH}$, calcium concentration and phosphate precipitation in granules can be found in a recent article by Mañas et al. [34]

\section{Discussion}

In this study, significant differences were observed between GSBRs in terms of performances and stability. These differences can firstly be explained by the fact that anoxic/aerobic conditions encouraged pre-denitrification (R1) whereas anaerobic/aerobic conditions favoured biological phosphorus removal (R2). Secondly, another important consequence of working with a mixture of carbon sources and a relatively short anaerobic period in R2 was the fact that a fraction of the easily biodegradable organic substrate was not removed anaerobically but was degraded in the aerobic period, which probably explains the growth of filamentous bacteria. Despite the fact that alternating anaerobic/aerobic conditions theoretically favour granulation by promoting carbon storage, filamentous bacteria that developed at the surface of granules had a negative impact on settleability and nitrification.

The stability of physical properties is a key issue for ensuring the long-term operation of a granular sludge reactor and it is characterized by proper settleability, which allows high biomass retention. Here, a very low sludge volume index $\left(15 \mathrm{mLg}^{-1}\right)$ and a stable, high MLSS concentration (up to $35 \mathrm{~g} \mathrm{~L}^{-1}$ ) were obtained in the GSBR operated with alternating anoxic/aerobic conditions (R1). In contrast, filamentous growth at the surface of granules (and finally in the bulk) progressively deteriorated the properties of granular sludge and degraded the performance reactor R2, which was operated with alternating anaerobic/aerobic phases (SVI $=70 \pm 15 \mathrm{mLg}^{-1}$, MLVSS dropped to $10 \mathrm{~g} \mathrm{~L}^{-1}$ ). Filamentous growth has previously been observed in aerobic granular sludge SBRs, resulting from a change in the wastewater composition, organic loading rate (OLR) or DO concentration $[13,15,35,36]$. It is generally accepted that filamentous growth is favoured at low oxygen availability. For instance Mosquera-Corral et al. [15] noted that aerobic granules lost their stability due to the outgrowth of filamentous bacteria when the DO was reduced to less than $40 \%$ of saturation. In the present study, despite similar aeration rates being imposed in both reactors, lower DO concentration was obtained at the beginning of the aerobic phase in R2 (anaerobic/aerobic) due to residual COD that was not removed during the non-aerated phase. This leads us to think that, here, filamentous growth was due to oxygen-limited growth of heterotrophic bacteria with an easily available carbon source (glucose, ethanol or residual acetate or propionate) at the beginning of the aerobic phase. The high COD:DO ratio maintained in the bulk at this period made it difficult for a dense biofilm to grow on the surface of the granules.

Traditionally, physiological studies have revealed that most of the filamentous bacteria have strictly aerobic metabolisms, although a small number of morphotypes have been claimed to have fermentative metabolisms [37], giving them selection advantages in anaerobic/aerobic systems. A plug-flow regime reactor like the SBR exerts a selection pressure on floc-forming bacteria through the high gradients of substrate preserved [38] and the conversion of easily biodegradable substrate to internal polymers [17]. In this work with a carbon source composed of glucose, propionate, acetate and ethanol, only a fraction of COD was removed anaerobically and converted to PHB. As the anaerobic period was relatively short, anaerobic fermentation did not play an important role in the reactor studied. The consequence was that a fraction of COD was not stored by PAO and was still present in the aerobic phase. This was detrimental to granule properties due to filamentous growth. A reactor with a longer pre-anaerobic phase or a pre-fermentation phase would probably be beneficial to granular sludge formation. An alternative solution would be to increase the aeration rate as shown by Mosquera-Corral et al. [15] but this would induce higher energy consumption.

The presence of nitrate during the feast period seemed critical for the stability of the granules in the first reactor (R1). A first explanation is that COD was fully removed by denitrification, thus ensuring the absence of COD in the aerobic phase (unlike in R2). Moreover, as shown by Wan et al. [18], the anoxic growth of heterotrophic bacteria in the inner layers could encourage aggregate densification. Both these situations are likely to enhance the strengthening of the granule structure and improve granule stability. In real wastewater, nitrate and nitrite are rarely present and cannot reasonably be injected continuously, except perhaps during start up to accelerate the formation of granules. This means that, for granular sludge stability, it is critical to maximize the amount of substrate used during the non-aerated (either anaerobic or anoxic) phase. For that reason, an adequate combination of anoxic, anaerobic and aerobic phases should be chosen, according to the ratio between COD, nitrogen and phosphorus in the influent [5].

The differences in terms of nutrient removal should also be pointed out. First, stable full nitrification was maintained in R1 and ammonium nitrifying bacteria $(\mathrm{AOB})$ were found to be distributed evenly throughout the granules. In contrast, filamentous heterotrophic bacteria growing at the periphery of granules in R2 made nitrification difficult and unstable, and FISH analysis confirmed that nitrifying bacteria were located behind the layer of filaments. On the other hand, SND (during the aerobic phase) was not observed in R1 but was probable in R2. This can be explained by the fact that less stored COD was available for denitrification during the aerobic period in a system working with a pre-anoxic phase (R1). Regarding phosphorus, the recent work of Mañas et al. [34] demonstrates that both biological and physical-chemical $P$ removal should be considered in EBPR granular sludge. Here, biological $P$ release was lower in $\mathrm{R} 1$ than in $\mathrm{R} 2$, which was logically explained by less VFA storage by PAO in anoxic conditions. But global P removal efficiency was similar and more stable in R1. This was because more calcium phosphate precipitated in R1, thanks to a higher $\mathrm{pH}$ due to denitrification. Although some authors have questioned the active role of calcium in EBPR [39,40], the effect of calcium precipitation on granular sludge performance and properties still needs more investigation. In this study, based on the calcium mass balance and considering that most of the calcium was removed via precipitation, the contribution of precipitation was estimated as in Mañas et al. [34]. Depending on the $\mathrm{pH}$, $60-70 \%$ of phosphorus removal was due to the precipitation mechanism in R1 whereas precipitation was responsible for $40-45 \%$ of $\mathrm{P}$ removal in $\mathrm{R} 2$. Hence the significant contribution of calcium 
phosphate precipitation should be considered when evaluating the fate of removed phosphorus in GSBR. Only part of the phosphorus removed is extracted as polyphosphate in the biomass and most of it can be accumulated in the granules, mainly as calcium phosphate (depending on the $\mathrm{pH}$, and the wastewater calcium and phosphate concentrations). Consequently, a dedicated work would be necessary to find the optimal extraction strategy for granules, considering the effect of precipitation on granule strength and stability.

\section{Conclusions}

In this study, significant differences were observed between two GSBRs working in anoxic/aerobic and anaerobic/aerobic conditions.

In the anoxic/aerobic reactor, very good settling properties for granular sludge $\left(\mathrm{SVI} \approx 20 \mathrm{mLg}^{-1}\right)$ and high MLSS concentration were stabilized. Full and stable nitrification was obtained. A pre-anoxic period resulted in the COD being used directly for denitrification, thus limiting biological phosphorus removal and SND but inducing more calcium-phosphate precipitation due to $\mathrm{pH}$ increase.

Filamentous bacteria were observed in the anaerobic/aerobic reactor and were detrimental to granular sludge properties and performances. A possible explanation is the presence of residual, easily biodegradable COD at the end of the anaerobic phase, which was then degraded aerobically. A critical point when using a mixture of organic carbon sources is thus to maximize the amount of substrate used during the non-aerated, either anaerobic or anoxic, phase.

\section{Acknowledgements}

The authors would like to acknowledge P. Boe, C. Caudan, S. Julien, E. Mengelle, M. Bounouba, and D. Delagnes for their helpful contributions to the execution of this work and C. Pouzet (T.R.I. imaging unit, FR3450, Castanet Tolosan) for her help with the confocal microscopy.

\section{References}

[1] M.K. de Kreuk, N. Kishida, M.C.M. van Loosdrecht, Aerobic granular sludge state of the art, Water Sci. Technol. 9 (2007) 75-81.

[2] E. Morgenroth, T. Sherden, M.C.M. Van Loosdrecht, J.J. Heijnen, P.A. Wilderer, Aerobic granular sludge in a sequencing batch reactor, Water Res. 31 (12) (1997) 3191.

[3] M. de Kreuk, J.J. Heijnen, M.C.M. van Loosdrecht, Simultaneous COD, nitrogen, and phosphate removal by aerobic granular sludge, Biotechnol. Bioeng. 6(2005) 761-769.

[4] G. Yilmaz, R. Lemaire, J. Keller, Z. Yuan, Simultaneous nitrification, denitrification, and phosphorus removal from nutrient-rich industrial wastewater using granular sludge, Biotechnol. Bioeng. 3 (2008) 529-541.

[5] Coma, S. Puig, M.D. Balaguer, J. Colprim, The role of nitrate and nitrite in a granular sludge process treating low-strength wastewater, Chem. Eng. J. 1 (2010) 208-213.

[6] Y.-Q. Liu, B. Moy, Y.-H. Kong, J.-H. Tay, Formation, physical characteristics and microbial community structure of aerobic granules in a pilot-scale sequencing batch reactor for real wastewater treatment, Enzyme Microb. Technol. 6 (2010) 520-525.

[7] A. Nor-Anuar, Z. Ujang, M.C.M. van Loosdrecht, M.K. de Kreuk, G. Olsson, Strength characteristics of aerobic granular sludge, Water Sci. Technol. 65 (2) (2012) 309-316.

[8] Y. Liu, J.H. Tay, The essential role of hydrodynamic shear force in the formation of biofilm and granular sludge, Water Res. 36 (avr. (7)) (2002) 1653-1665.

[9] Y. Liu, S.-F. Yang, J.-H. Tay, Improved stability of aerobic granules by selecting slow-growing nitrifying bacteria, J. Biotechnol. 108 (2) (2004) 161.

[10] B.S. McSwain, R.L. Irvine, P.A. Wilderer, The effect of intermittent feeding on aerobic granule structure, Water Sci. Technol. 12 (2004) 19-25.
[11] B.Y.P. Moy, J.H. Tay, S.K. Toh, Y. Liu, S.T.L. Tay, High organic loading influences the physical characteristics of aerobic sludge granules, Lett. Appl. Microbiol. 6 (2002) 407-412.

[12] L. Qin, Y. Liu, J.-H. Tay, Effect of settling time on aerobic granulation in sequencing batch reactor, Biochem. Eng. J. 21 (1) (2004) 47.

[13] J.H. Tay, Q.S. Liu, Y. Liu, The effects of shear force on the formation, structure and metabolism of aerobic granules, Appl. Microbiol. Biotechnol. 57 (Oct. (1-2)) (2001) 227-233.

[14] J.J. Beun, A. Hendriks, M.C.M. Van Loosdrecht, E. Morgenroth, P.A. Wilderer, J.J. Heijnen, Aerobic granulation in a sequencing batch reactor, Water Res. 33 (juill. (10)) (1999) 2283-2290.

[15] A. Mosquera-Corral, M.K. de Kreuk, J.J. Heijnen, M.C.M. van Loosdrecht, Effects of oxygen concentration on $\mathrm{N}$-removal in an aerobic granular sludge reactor. Water Res. 12 (2005) 2676-2686.

[16] S. Tsuneda, T. Ohno, K. Soejima, A. Hirata, Simultaneous nitrogen and phosphorus removal using denitrifying phosphate-accumulating organisms in a sequencing batch reactor, Biochem. Eng. J. 27 (janv. (3)) (2006) 191-196.

[17] M.C.M. Van Loosdrecht, M.A. Pot, J.J. Heijnen, Importance of bacterial storage polymers in bioprocesses, Water Sci. Technol. 1 (1997) 41-47.

[18] J.Wan, Y. Bessiere, M. Spérandio, Alternating anoxic feast/aerobic famine condition for improving granular sludge formation in sequencing batch airlift reactor at reduced aeration rate, Water Res. 20 (2009) 5097-5108.

[19] J. Wan, M. Sperandio, Possible role of denitrification on aerobic granular sludge formation in sequencing batch reactor, Chemosphere 2 (2009) 220-227.

[20] P.M.J. Janssen, K. Meinema, H.F. van der Roest, Biological Phosphorus Removal: Manual for Design and Operation, IWA Publishing, 2002.

[21] T. Mino, W. Liu, F. Kurisu, T. Matsuo, Modelling glycogen storage and denitrification capability of microorganisms in enhanced biological phosphate removal processes, Water Sci. Technol. 31 (janv. (2)) (1995) 25-34.

[22] Afnor Éd., Qualité de l'eau, in: Recueil de normes, Afnor Editions, 1994.

[23] A. Filali, Y. Bessiere, M. Sperandio, Effects of oxygen concentration on the nitrifying activity of an aerobic hybrid granular sludge reactor RID A-1878-2012, Water Sci. Technol. 65 (2) (2012) 289-295.

[24] R. Amann, B.M. Fuchs, S. Behrens, The identification of microorganisms by fluorescence in situ hybridisation, Curr. Opin. Biotechnol. 12 (juin (3)) (2001) 231-236.

[25] B.K. Mobarry, M. Wagner, V. Urbain, B.E. Rittmann, D.A. Stahl, Phylogenetic probes for analyzing abundance and spatial organization of nitrifying bacteria, Appl. Environ. Microbiol. 62 (janv. (6)) (1996) 2156-2162.

[26] M. Wagner, G. Rath, H.-P. Koops, J. Flood, R. Amann, In situ analysis of nitrifying bacteria in sewage treatment plants, Water Sci. Technol. 2 (1996) 237-244.

[27] H. Daims, P.H. Nielsen, J.L. Nielsen, S. Juretschko, M. Wagner, Novel Nitrospiralike bacteria as dominant nitrite-oxidizers in biofilmsfrom wastewater treatment plants: diversity and in situ physiology, Water Sci. Technol. 41 (juin (4-5)) (2000) 85-90.

[28] D. Pandolfi, M.-N. Pons, M. da Motta, Characterization of PHB storage in activated sludge extended filamentous bacteria by automated colour image analysis, Biotechnol. Lett. 29 (août (8)) (2007) 1263-1269.

[29] A. Mañas, B. Biscans, M. Spérandio, Biologically induced phosphorus precipitation in aerobic granular sludge process, Water Res. 12 (2011) 3776-3786.

[30] V. Ivanov, S.T.-L. Tay, Q.-S. Liu, X.-H. Wang, Z.-W. Wang, J.-H. Tay, Formation and structure of granulated microbial aggregates used in aerobic wastewater treatment, Water Sci. Technol. 7 (2005) 13-19.

[31] Y.-M. Zheng, H.-Q. Yu, G.-P. Sheng, Physical and chemical characteristics of granular activated sludge from a sequencing batch airlift reactor, Process Biochem. 40 (févr. (2)) (2005) 645-650.

[32] J.K. Park, L.M. Whang, J.C. Wang, G. Novotny, A biological phosphorus remova potential test for wastewaters, Water Environ. Res. 73 (mai (3)) (2001) 374-382.

[33] N. Jardin, H.J. Pöpel, Behavior of waste activated sludge from enhanced biological phosphorus removal during sludge treatment, Water Environ. Res. 68 (6) (1996) 965-973

[34] A. Mañas, M. Pocquet, B. Biscans, M. Sperandio, Parameters influencing calcium phosphate precipitation in granular sludge sequencing batch reactor, Chemical Engineering Science, (2012) http://dx.doi.org/10.1016/j.ces.2012.01.009.

[35] N. Schwarzenbeck, R. Erlay, P.A. Wilderer, Aerobic granular sludge in an SBRsystem treating wastewater rich in particulate matter, Water Sci. Technol. 12 (2004) 41-46.

[36] Y.-M. Zheng, H.-Q. Yu, S.-J. Liu, X.-Z. Liu, Formation and instability of aerobic granules under high organic loading conditions, Chemosphere 63 (10) (2006) 1791.

[37] G. Nowak, G.D. Brown, Characteristics of Nostocoida limicola and its activity in activated sludge suspension, Res. J. Water Pollut. Control Fed. 62 (mars (2)) (1990) 137-142.

[38] A.M.P. Martins, K. Pagilla, J.J. Heijnen, M.C.M. van Loosdrecht, Filamentous bulking sludge - a critical review, Water Res. 38 (févr. (4)) (2004) 793-817.

[39] C.F.C. Bonting, G.J.J. Kortstee, A. Boekestein, A.J.B. Zehnder, The elemental composition dynamics of large polyphosphate granules in Acinetobacter strain 210A, Arch. Microbiol. 159 (mai (5)) (1993) 428-434.

[40] C. Schönborn, H.-D. Bauer, I. Röske, Stability of enhanced biological phosphorus removal and composition of polyphosphate granules, Water Res. 35 (Sept. (13)) (2001) 3190-3196. 